
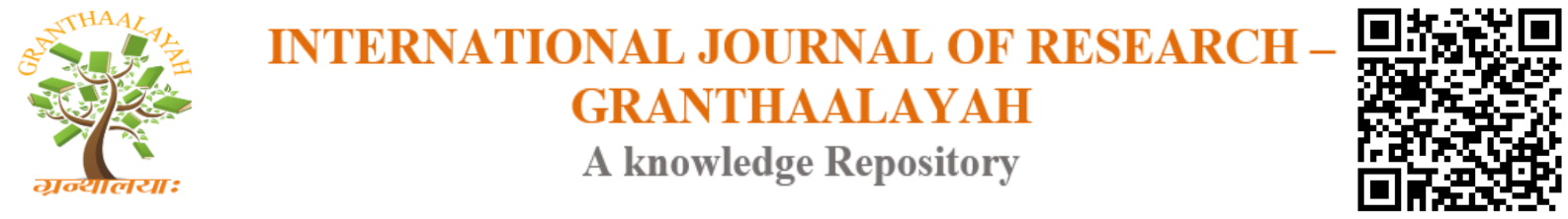

Social

\title{
EFFECT OF YOGIC PRACTICES ON FLEXIBILITY AMONG ANNAMALAI UNIVERSITY STUDENTS
}

\author{
Dr.V. Suseela ${ }^{1}$, B.Srilakshmidevi ${ }^{2}$ \\ ${ }^{1}$ Assistant Professor, Center for Yoga Studies, Annamalai University, India \\ ${ }^{2}$ Research Scholar (Fulltime), Center for Yoga Studies, Annamalai University, India
}

\begin{abstract}
The aim of the study was to determine the Effect of yogic practices on flexibility among Annamalai University students 20 subjects were selected from 'Annamalai University', chidambaram students were selected. They were selected randomly and their age group was between 15 to 30 years. Single group formed. All are in Experimental group. The experimental group participated in yogic practice training and for 6 weeks. The data were collected in the beginning and at the end. The training schedule was prepared systemically. The significance was tested at 0.05 levels.
\end{abstract}

Keywords: Yogic Practices; Students; Physical; Mental \& Scientific System.

Cite This Article: Dr.V. Suseela, and B.Srilakshmidevi. (2017). "EFFECT OF YOGIC PRACTICES ON FLEXIBILITY AMONG ANNAMALAI UNIVERSITY STUDENTS." International Journal of Research - Granthaalayah, 5(7:SE), 63-67. https:// doi.org/10.29121/granthaalayah.v5.i7(SE).2017.2124.

\section{Introduction}

Yoga is a scientific system of physical and mental practices that originated in India more than three thousand years ago. Its purpose is to help each one of us achieve our highest potential and to experience enduring health and happiness. With Yoga, we can extend our healthy, productive years far beyond the accepted norm and, at the same time, improve the quality of our lives. The branch of Yoga that forms the main focus of my teaching work with both adults and children is called Hatha Yoga.

Hatha Yoga begins by working with the body on a structural level, helping to align the vertebrae, increase flexibility, and strengthen muscles and connective tissue. At the same time, internal organs are toned and rejuvenated; the epidermal, digestive, lymphatic, cardiovascular, and pulmonary systems are purified of toxins and waste matter; the nervous and endocrine systems are balanced and toned; and brain cells are nourished and stimulated. The end result is increased mental clarity, emotional stability, and a greater sense of overall well-being. Yoga is a form of exercise based on the belief that the body and breath intimately connected with the mind. By 
controlling the breath and holding the body in steady poses, or asana, yoga creates harmony. Yoga is means of balancing and harmonizing the body, mind and emotion and is a tool that allows us to withdraw from the chaos of the world and find a quite space within.

\section{Objectives of the Study}

The aim of the study was to find out the Effect of yogic practices on Flexibility among Annamalai university students.

\section{Methodology}

For the purpose of the study 20 students were selected randomly from Annamalai university students and their age group was between 18- 30 years were selected. Single group formed. All are in Experimental Group. The experimental group participated in yogic practices for 6 week there is no control group. The data were collected in the beginning and at the end. The training schedule was prepared systemically. The significance was tested at 0.05 levels.

\section{Administration of test \\ Flexibility \\ Equipment}

The below figure shows the equipment to measure the v-sit and reach test.it will need sale, inchtape, pencil, marker. Flexibility was measured with V-Sit and Reach test.

\section{Description}

The subject responses are scored. In addition, the results are tabulated. The flexibility of the pre and post test scores of experimental group have been analyzed and presented in the below. The table shows the scores of the $\mathrm{v}$-sit and reach test.

\section{Scoring}

The total score for a subject ranges from 11 to 23 . The individual interpretation can be done through V-sit and reach flexibility Norms and proceeds and percentiles (\%ile).

\section{Interpretation}

Female:

Age : Under 30

$>14$ very poor

15-16 poor

$17-19$ average

20-21 above average

22 good

$<23$ excellent

\author{
Male: \\ Age : under 30 \\ $>11$ very poor \\ 12-13 poor \\ 14-17 average \\ 18-19 above average \\ 21 good \\ $<22$ excellent
}

\section{Training protocol}

The experimental group under went training that consist of preparatory practice and loosening practice and seven asana practice session, in a week 5 days for 6 weeks. In the morning, yogic training administrated from Monday to Friday respectively. 
Training Format

\begin{tabular}{|l|l|}
\hline Name of the asana & Duration of asana \\
\hline $\begin{array}{l}\text { ASANAS } \\
\text { Stretching practices }\end{array}$ & 5 minutes \\
\hline Loosening practices & 5 minutes \\
\hline Surynamaskara & 5 rounds \\
\hline $\begin{array}{l}\text { Padmasana } \\
\text { Pawanamukthasana }\end{array}$ & 2 times in each, 4 minutes \\
\hline $\begin{array}{l}\text { Trikonasana } \\
\text { Padahastasana }\end{array}$ & 4 times in each, 6 minutes \\
\hline $\begin{array}{l}\text { Pachimothasana } \\
\text { Makrasana }\end{array}$ & 4 times in each, 8 min \\
\hline Kabalapathi, bastrika & 5 minutes \\
\hline Deep relaxation technique & 20 minutes \\
\hline
\end{tabular}

\section{Experimental Design and Statistical Procedure}

The experimental group design used in this study was random group design involved ten subjects were included both male and female. Analysis of Variance (ANOVA) was used for computing. Analysis of variance on flexibility of yogic practice group through v-sit and reach test is tabulated in table 1 and graphically represented in figure-1.

Mean and standard deviations on flexibility among Annamalai University students T-Test

\begin{tabular}{|r|c|l|l|l|}
\multicolumn{5}{c}{ Paired Samples Statistics } \\
\hline & Mean & N & Std. Deviation & Std. Error Mean \\
\hline Pair 1 VAR00001 & 15.8889 & 27 & 7.62250 & 1.46695 \\
VAR00002 & 18.3704 & 27 & 7.20656 & 1.38690 \\
\hline
\end{tabular}

Paired Samples Correlations

\begin{tabular}{|lll|l|l|l|}
\hline & & \multicolumn{1}{|c|}{$\mathbf{N}$} & Correlation & \multicolumn{1}{c|}{ Sig. } \\
\hline Pair 1 & VAR00001 & $\&$ & 27 & .910 & .000 \\
\hline
\end{tabular}

Paired Samples Test

\begin{tabular}{|c|c|c|c|c|c|c|c|c|}
\hline & \multicolumn{5}{|c|}{ Paired Differences } & \multirow[b]{3}{*}{$\mathbf{t}$} & \multirow[b]{3}{*}{ df } & \multirow{3}{*}{$\begin{array}{l}\text { Sig. (2- } \\
\text { tailed) }\end{array}$} \\
\hline & \multirow[b]{2}{*}{ Mean } & \multirow{2}{*}{$\begin{array}{c}\text { Std. } \\
\text { Deviation }\end{array}$} & \multirow{2}{*}{$\begin{array}{l}\text { Std. } \\
\text { Error } \\
\text { Mean }\end{array}$} & \multicolumn{2}{|c|}{$\begin{array}{c}95 \% \text { Confidence } \\
\text { Interval of the } \\
\text { Difference }\end{array}$} & & & \\
\hline & & & & Lower & Upper & & & \\
\hline $\begin{array}{ll}\text { Pair } & \text { VAR00001 } \\
1 & \text { VAR00002 }\end{array}$ & -2.48148 & 3.17890 & .61178 & -3.73901 & -1.22395 & $\begin{array}{l}- \\
4.056\end{array}$ & 26 & .000 \\
\hline
\end{tabular}


The flexibility of the pre and post test scores of experimental group have been analyzed and presented in the below Table I.

It is clear from Table 1 that there is a significant improvement in Annamalai university students on flexibility, as $t(d f 26)=4.670, p<0.05$.the standard deviation of pretest is 7.622 and the post test of standard deviation is 1.38690 . It also clearly shows that flexibility increased from 15.889 to $18.370 \mathrm{~cm}$ through yogic practices and recorded $10.05 \%$ increase (MD $-2.48148 \mathrm{~cm}$ ). It is interpreted that yogic practice showed significant increase $10.05 \%$ in flexibility for students.

The below graphical representation of the pretest and posttest of flexibility mean and standard deviation of annamalai university students.

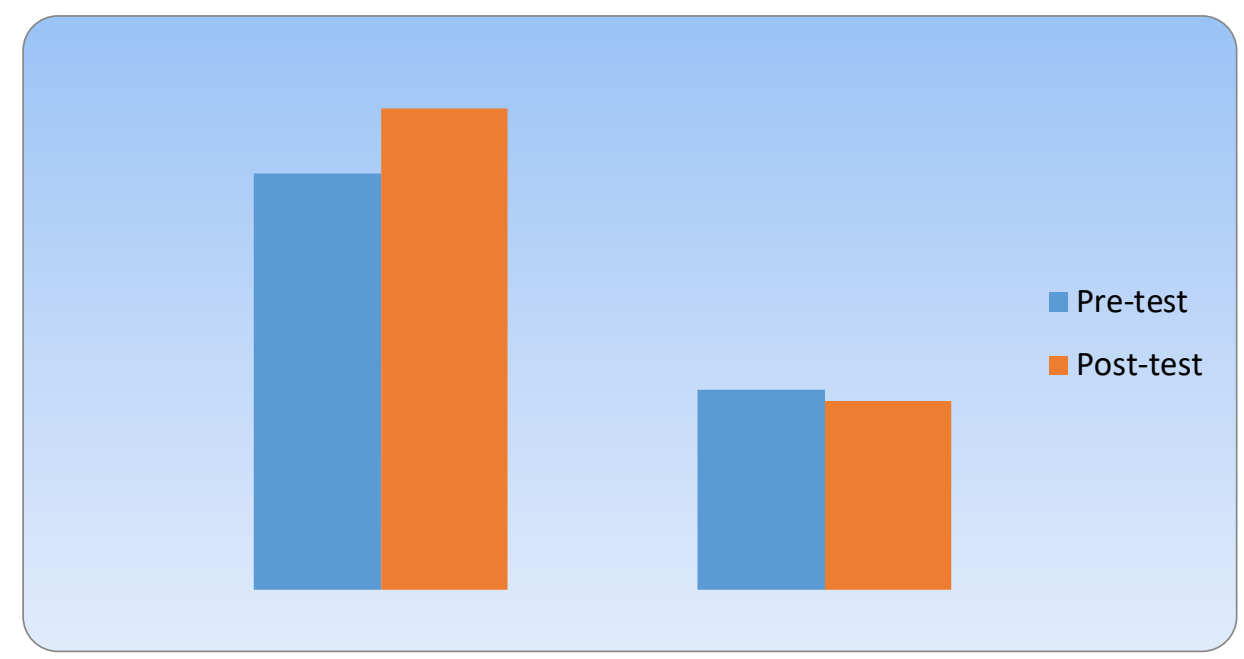

Figure 1: Changes in flexibility from pre to post on annamalai university students

\section{Conclusion}

The result of the study shows there is significant difference between yogic practice group on flexibility. Moreover, the result of the study shows that there is significant improvement in flexibility compared to pre -test.

\section{References}

[1] AraujoCGS.Flexitest: an innovative flexibility assessment method. Champaign: Human Kinetics; 2003.205p.Boucher S. Yoga for Cancer. Yoga J. 2007.Retrievedxsfrom http://www.yogajournal.com/health/126

[2] Golden, S. A. R. (2011). An Analysis Of Mental Stress In Heavy Alloy Penetrator Project, Tiruchirappalli. SELP Journal of Social Science, 13.

[3] Golden, S. A. R. (2011). Strategy For Success Of Human Beings:-Time Management. Department Of BBA, St. Joseph's College, Trichy, 388(390), 0.

[4] Golden, S. A. R. (2017). Recent Research in Social Sciences \& Humanities. EduPedia Publications (P) Ltd.

[5] Jayachandran and Ananthanarayanan T.V.-Two case studies of asana therapy in the management of mental retardation. Paper presented at the National, Symposium 'Yoga, Brain and consciousness NIMHANS, Bangalore,India. (1982)Jan. PP. 1-2. 
[6] Nagendra H.R. and Nagarathna R.-Initial studies for Yoga Therapy for the Mentally Retarded. Vivekananda YOCTAS, (1984) Report No.VKYOCTAS/BN/014184.

[7] Rajyalakshmi- Effect of certain Yogasanas on Mentally Retarded children, Mimeograph of the Indian Institute of allied sciences, Tirupathi (1979).

[8] Regi, S. B., \& Golden, S. A. R. (2014). A Descriptive Study On The Role Of Consumer Psychology And Behaviour In Product Purchasing. Indian Streams Research Journal, 3 (12), 1, 6.

[9] Shogren, K. A., \&Plotner, A. J. (2012). Transition planning for Students with intellectual disability, autism, or other disabilities: Data from the National Longitudinal Transition Study-2. Intellectual and Developmental Disabilities, 50, 16-30.

[10] Uma K, Nagendra HR, Nagarathna R, et al. The integrated approach of yoga: a therapeutic tool for mentally retarded children: one-year controlled study. J MentDefic Res. 1989; 33:415-421. 